\title{
Influence of the pricing policy in the Russian power industry on the gross domestic product (GDP) dynamics
}

\author{
I. A. Korolev, L. D. Khabatchev \& V. M. Makarov \\ St. Petersburg State Polytechnical University, Russian Federation
}

\begin{abstract}
Results of implementing any pricing policy in the Russian power industry have a direct effect on the economic effectiveness of all sectors of the national economy due to the use of electric power for any activity or manufacture of any product. Intersectoral relations existing in the economy intensify and multiply the influence of the price factor in the power industry: price changes have an impact on the expenses of sectors both directly and indirectly. For example, the purchase cost of raw materials produced by energy-intensive sectors greatly influences the manufacturing cost of their own products. Since the amount of the gross domestic product (GDP) (the constituents of which are salary fund, taxes, the gross profit of sectors of the national economy) is an integral indicator of economic activities of the national economy, this article analyzes the influence of the pricing policy in the power industry on the basic national GDP indicators and represents solutions to two most critical issues in the Russian power industry: when marginal electricity prices decrease in the day-ahead market of the wholesale electricity and capacity market after returning to the governmental regulation of electricity rates of nuclear and hydraulic power plants, and when the cross-subsidization system in the Russian power industry is liquidated.

Keywords: gross domestic product, intersectoral balance, multiplicative effect, pricing policy, power industry, cross-subsidization, marginal pricing.
\end{abstract}

\section{Introduction}

Due to the reforms in the Russian power industry, activities of monopoly vertically integrated power companies are divided into three areas: generation, transmission and distribution, and electricity sales. Electric power generation and 
sales have become a competitive area and attracted investments of such foreign investors as Fortum (Finland), Enel (Italy), E.On (Germany) in the authorized capital of companies operating in this industry. The sales sector is represented by both private retail companies and government-controlled "last resort suppliers". The latter supply power to the population and are obliged to enter into a power supply agreement with any consumer addressed them. Electric power transmission, distribution and dispatching operations remain governmentcontrolled.

The operating power market in Russia is represented by a two-tier model including wholesale and retail markets. Electricity and capacity sales are carried out separately in the wholesale market: electricity is traded in the day-ahead market (DAM) and balancing market; capacity prices are determined by annual competitive capacity procedures $(\mathrm{CCP})$. The average electric power selling price in retail markets may be translated from the wholesale market in both double-rate and single-rate forms inclusive of the capacity price.

In the last years, the price increase in the final single-rate electricity price was largely influenced by the following factors:

- participation of nuclear and hydraulic power plants in the DAM;

- operation of ineffective generating power plants of so-called "must-run generation", which operational costs may be more than 5 times higher than the capacity price during competitive capacity procedures, and which withdrawal from the market is presently impossible due to technological or social aspects;

- burden for all consumers as an administrative tool for investing in the construction of a new power generation plant to pay under capacity supply agreements (CSA), where the government provides guarantees to contractors for a period exceeding 10 years after the commissioning of a power plant to receive fixed incomes during capacity sales;

- maintenance of overstated reserves in the energy system;

- transition of a majority of electric grid companies from a costly regulation method to the return on invested capital method (Regulatory Asset Base method) with a short capital return period;

- restraints for the growth of electricity prices for households (population) that resulted in the emergence of a deeply ingrained cross-subsidization system in the power industry when one group of consumers partially pays for liabilities of the other group of consumers.

Frequent changes in the legal framework and operational rules in the power markets worsen the current situation in the Russian power industry.

Let's consider in detail two most critical issues influencing the growth of final electricity prices: participation of nuclear and hydraulic power plants in the DAM and cross-subsidization.

Since the CCP procedure guarantees incomes to nuclear and hydraulic power plants to maintain investments and the cost of electricity generated by such power plants is considerably lower compared to the power plants operating on 
organic fuel, their participation in the day-ahead market, where the marginal pricing system operates (the DAM price is accepted as equal to the highest price quotation of a power station [5]), brings excess profits to such power stations. According to the authors' assessments, their excess profits amounted to RUR 132 bln (or EUR 3.2 bln) in 2011 [1].

The cross-subsidization volume is much higher. According to the authors' assessments, it was RUR 266 bln (or EUR 6.4 bln) in 2011 [2]. Initially, the use of the cross-subsidization system for pricing in the Russian power industry was intended by governmental authorities as a mechanism to protect low-income population against increasing expenses for consumed electric energy under the conditions of galloping inflation in the 1990s. So far, the Russian economic environment has changed and it has become obvious that these practices should be cleared off. However, such a solution may lead to a social explosion. The political factor (frequent elections) has dominated over the economic factor in the last 15 years, thus preventing from solving this problem. As a result, the ratio between the regulated electricity rate for population and electricity prices for Russian industrial consumers was 0.88 in 2012, though actually it should have been over one. The explanation is, as follows: when electricity is supplied to the population, numerous transformations are required up to the low-voltage level with generation of accompanying process losses in the power supply network infrastructure. For example, similar ratios in some foreign power markets are 1.65 in the United Kingdom, 1.77 in the USA and 1.88 in Finland [4].

According to the authors' assessments, the electricity price for Russian industrial consumers with a connected capacity of over $750 \mathrm{kVA}$ exceeded electricity prices for US industries by 7,2\% and was 5.81 Euro cent in 2012 [7]; the electricity price for industrial consumers with a connected capacity of below $750 \mathrm{kVA}$ exceeded prices not only in the USA but also in some European countries: Bulgaria, Montenegro, Bosnia and Herzegovina and came to 8.30 Euro cents and approached the price of industrial consumers, i.e. 9.15 Euro cents in Finland [6].

If the existing growth rate for electricity prices is maintained, energyintensive industries will be forced to either massively set up their own power supply sources or shift their production volumes towards foreign markets with more favorable pricing policies. However, it should be noted that there are some positive changes in dealing with such problem: amendments to the power sector legislation were accepted in 2013. They introduced the term "crosssubsidization" in the power industry and a mechanism for its reduction, including by certain Russian regions.

If nuclear and hydraulic power plants return to the governmental regulation of electricity rates and cross-subsidization is liquidated, the economical effect will be different since in the first case electricity prices for population will remain unchanged and prices for other consumers will drop. As regards to the second case, electricity prices for population will grow and prices for other consumers will also drop. In this regard, it is interesting to analyze how the pricing policy in the Russian power industry influences the basic indicators of the gross domestic product at various electricity price dynamics in groups of power consumers. 


\section{Multiplicative effect of the price factor of the power market on the economic activities of sectors of the national economy}

Growth of electricity prices for sectors of the national economy (especially, energy-intensive sectors) leads to the growth of production cost, which may result in a boost, in various proportions, of selling prices for products manufactured by such sectors and subsequent diminution in the demand for such products in internal or external commodity markets and a decrease in the added value in sectors. This will become a reason for reduced tax deductions into the budget, salary fund (SF) or subsequent investments in the development of own productions.

Alternatively, reduction of final energy prices can generate a positive effect for the economy. For example, it can initiate an increase in the industrial production growth rate due to the release of enterprises' financial resources intended to purchase electric power.

Existing intersectoral relations intensify the influence of the price factor. For example, electricity price changes in the metallurgical industry can not only influence the amount of its added value, i.e. gross profits or salary fund, or result in proportional changes of final product prices, but also adjust the cost in sectors, where products of this industry form a substantial part. In fact, it is common knowledge that the cost of ferrous metals in prices of shipped products at machine-building enterprises and enterprises producing construction materials is $11 \%$ and $7 \%$, correspondingly.

The authors set up an algorithm to simulate a multiplicative effect of electricity prices. Its scenario depends on the national rate policy: the return of nuclear and hydraulic power plants to the governmental regulation will reduce the demand of the power sector for investments and, consequently, decrease the volume of production of a number of industries, providing earlier orders of nuclear and hydraulic power plants; on the other part, a reduction in the most efficient load on sectors as regards to purchased electric energy will exceed the overall negative effect of reduced investments leading to an increase in the value added of sectors, including the SF, provided that $73 \%$ of received funds are allocated by households for direct consumption of goods and services, mean an additional economic demand that will initiate a new growth of the gross value added of sectors. Thus, an increase in the salary fund in the above multiplicative effect formation scenario will again increase the gross output and, consequently, the gross value added of all national economic sectors, but to a lesser degree, and so on till the incremental SF amount in subsequent iterations reduces to zero.

If cross-subsidization is eliminated, the value added of the power sector remains unchanged while it will initially increase by an amount of the saved money in other sectors after a reduction in the electricity price for them, but nonlinearly rather than in direct proportion due to a reduction in the aggregate demand of the employed population with a growth of electricity prices for the latter.

The multipliers for the gross output growth will be total expenditure coefficients defined by the authors based on the 2003 Russian Intersectoral 
Balance elaborated by the State Statistics Committee of the Russian Federation. The aggregate of the total expenditure coefficients is represented as a matrix of total expenses in the structural relation, widely known from the input-output theory [3], between gross and final products:

$$
X=(E-A)^{-1} Y
$$

where:

$X$ - vector of productivity rates in national sectors; $E$ - identity matrix; $A-$ matrix of direct expenses; $Y$ - vector of sector products final consumption; $(E-A)^{-1}$ - inverse matrix or total expenditure matrix.

From another hand, the multiplier for the gross output growth can be a regression coefficient in the equation built by the authors and representing regression relationship between the GDP and expenses of households over a period of 2002-2012:

$$
X=1.23 Y+15276
$$

where:

$X$ - amount of the GDP, bln RUR; $Y$ - expense for final consumption of households, bln RUR.

The regression coefficient shows that, at an average, the gross domestic product increases by RUR 1.23 per Ruble of the growth of household expenses.

\section{Calculation results}

The calculations made with the original 2011 data gave the following results:

If nuclear and hydraulic power plants return to the governmental regulation of electricity rates provided that the required investment volume is maintained for them, their profits may reduce by RUR $133 \mathrm{bln}$, but the average selling price of electric power for all consumers may decrease by $9.62 \%$. In this case, the direct effect, depending on the sector of the national economy, may be the amounts shown in Table 1. The effect in sectors changes depending on their energy intensity (the higher it is the more saving is with the reduction in the purchased electric energy cost) and a share in the structure of production of raw materials produced by energy-intensive sectors.

Here, the maximum primary effect of reduction in electricity prices is experienced by industrial sectors, since they consume over $53 \%$ of electric power generated in Russia. If nuclear and hydraulic power plants return to the governmental regulation, the total growth of added value will be over RUR 67 bln only in manufacturing industries or $50 \%$ of the total growth of added value in all sectors.

The final multiplicative effect as the GDP growth in all sectors (18 iterations were made under the above-mentioned multiplicative effect scenario) will be RUR 234 bln (the market multiplier will be 1.76), including: the salary fund will increase by RUR 113 bln and the gross profit of sectors will grow by RUR 78 bln, tax deductions (including taxes on products) will increase by RUR 43 bln. 
Table 1: Direct effect from the reduction in purchased electric energy cost in certain sectors of the Russian national economy in 2011 (excluding taxes on products), bln RUR.

\begin{tabular}{|c|c|c|c|c|c|c|c|c|}
\hline \multirow[b]{2}{*}{ Title } & \multirow[b]{2}{*}{$\begin{array}{l}\text { Mineral } \\
\text { production }\end{array}$} & \multicolumn{3}{|c|}{ Manufacturing industries: } & \multirow[b]{2}{*}{$\begin{array}{l}\text { Transport } \\
\text { and } \\
\text { communica- } \\
\text { tion }\end{array}$} & \multirow[b]{2}{*}{$\begin{array}{l}\text { Agricul- } \\
\text { ture }\end{array}$} & \multirow[b]{2}{*}{$\begin{array}{l}\text { The } \\
\text { other } \\
\text { sectors }\end{array}$} & \multirow[b]{2}{*}{$\begin{array}{l}\text { Total } \\
\text { by } \\
\text { sectors }\end{array}$} \\
\hline & & Total & $\begin{array}{c}\text { including } \\
\text { metal- } \\
\text { lurgical } \\
\text { production } \\
\end{array}$ & $\begin{array}{l}\text { including } \\
\text { chemical } \\
\text { production }\end{array}$ & & & & \\
\hline $\begin{array}{l}\text { Total } \\
\text { growth of } \\
\text { added } \\
\text { value, } \\
\text { including: }\end{array}$ & 21 & 46 & 18 & 6 & 19 & 3 & 44 & 133 \\
\hline $\begin{array}{l}\text { Salary } \\
\text { fund }\end{array}$ & 9 & 18 & 6 & 4 & 8 & 1 & 42 & 78 \\
\hline $\begin{array}{l}\text { Gross } \\
\text { profit }\end{array}$ & 6 & 25 & 12 & 2 & 10 & 2 & 4 & 47 \\
\hline $\begin{array}{l}\text { The other } \\
\text { taxes on } \\
\text { production }\end{array}$ & 1 & 3 & 0 & 0 & 1 & 0 & 3 & 8 \\
\hline
\end{tabular}

A part of additional tax revenues could have been allocated to co-financing for upgrading ineffective power plants with the power generation price close to or higher than the equilibrium DAM price to get even higher reduction the purchased electric energy cost for sectors of the national economy.

If cross-subsidization between different categories of consumers is eliminated, the market multiplier will be lower (it will be 1.37) compared to the return of nuclear and hydraulic power plants to the governmental regulation, because the mandatory increase in electricity prices for households will reduce the aggregate demand in the economy. The calculations show that if electricity prices for households increase by $10 \%$, the aggregate demand for other consumer goods to the extent of the purchased electric energy cost will reduce by $20 \%$; if electricity prices increases by $20 \%$, the demand will reduce by $40 \%$, etc. (fig. 1 ). Additionally, corresponding government compensation will be required to pay the bills of low-income citizens.

If cross-subsidization is liquidated in a single stage, the final multiplicative effect as the GDP growth in all sectors will be RUR 365 bln (the market multiplier is 1.37), including: the salary fund will increase by RUR 176 bln and the gross profit of sectors will grow by RUR 122 bln; tax deductions will increase by RUR 68 bln. The average selling price of electric power will increase by $113 \%$ (more than twice) for the Russian population, generally, and reduce by $15 \%$ for other consumers. 


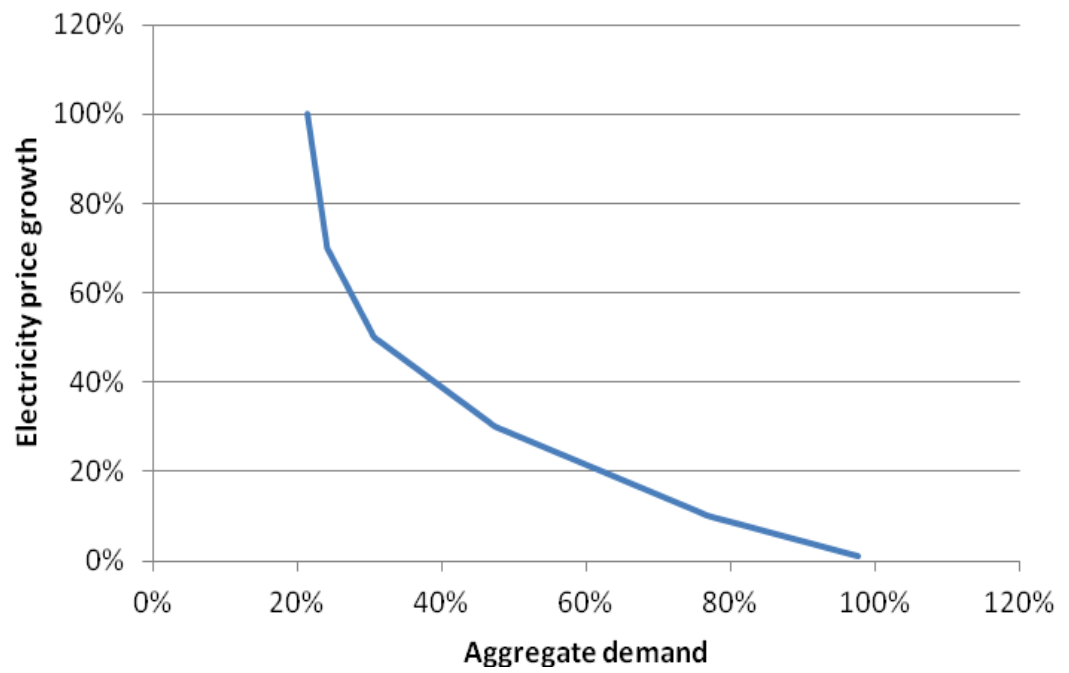

Figure 1: Dependence of the aggregate demand for consumer goods (within the cost of purchased electric energy) on growth of electricity prices for households.

The authors additionally calculated the lowest potential period of time (in years) to refuse to use cross-subsidization practices, where the optimality criterion was defined as maximum tax revenues into the budget. Generally, it was 5.5 years in Russia. In this case, the annual growth rate of electricity prices for population may be $118 \%$ (124\% adjusted for inflation) with reference to the electricity rate in 2011. It is so-called "soft" way to avoid cross-subsidization, i.e. with no acute social disruption. Here, the effect of abandoning crosssubsidization can not only compensate budget expenses for higher electricity costs for low-income population groups, but also increase the governmental subsidization volume for housing and utility expenses (HUE) of low-income population by RUR 3.6 bln $(6 \%$ of the total amount of allocated subsidies for HUE payment in 2011).

If the optimality criterion is defined as minimum tax revenues into the budget (approaching zero), the period required to refuse to use cross-subsidization practices in the Russian power industry may be 2.6 years, and growth of electricity prices for population will not exceed 139\% (145\% adjusted for inflation) of the electricity rate in 2011. It is a 'harder' way to abandon crosssubsidization. Faster rates of abandoning cross-subsidization will be absolutely negative for the national economy (except for the dynamics of profits received from activities of export-oriented energy-intensive enterprises only) since the energy-intensive effect as the growth of tax revenues into the budget due to reduced electricity prices for all sectors will be totally neutralized by the reduced demand on the part of households with a sharp increase in the electricity cost for the latter. 
It should be noted that this calculation is given generally for Russia. Since the cross-subsidization volume in Russian regions, industrial potential of enterprises, the number of low-income population greatly differ from each other, assessment of the period required to abandon cross-subsidization in the regional aspect should be conducted individually for every region.

\section{Conclusions}

The GDP dynamics is determined by the economic development of all sectors of the national economy. The pricing policy in the Russian power industry has both a direct influence on economic activities of energy-intensive enterprises and an indirect influence on activities of all other sectors of the national economy due to intersectoral relations. Integrated accounting of assessments of the pricing policy influence in the power industry on the major national macroeconomic indicators, using a multiplicative approach proposed by the authors, will provide a considerable increase in its efficiency, balance and effectiveness. The calculations made by the authors confirmed, that the influence level of the pricing policy is defined by special features of price formation for various power consumer categories.

When the pricing policy is pursued, special attention should be paid to the final economic effect for households, since the dynamics of expenses incurred by the latter is the basic GDP growth driver.

\section{References}

[1] Korolev I.A., Makarov V.M. Winning producer of the wholesale market of electricity and capacity. St. Petersburg State Polytechnical University Journal. Economics, 6 (161), pp. 82-86, 2012. (rus)

[2] Korolev I.A., Khabatchev L.D. The directions and principles of elimination the system of the cross-subsidization in the Russian power industry. St. Petersburg State Polytechnical University Journal. Economics, 6-1 (209), pp. 54-64, 2013. (rus)

[3] Wassily Leontief. Input-Output Economics. Second edition, OUP USA, 1986.

[4] Key World energy statistics 2013, International Energy Agency. (Available at: http://www.iea.org/)

[5] Planning our electric future: a White Paper for secure, affordable and low carbon electricity, Department of Energy and Climate Change, 2011. (Available at: http://www.official-documents.gov.uk/document/cm80/8099 /8099.pdf)

[6] Electricity prices for industrial consumers, from 2007 onwards - bi-annual data, Eurostat (Available at: http://epp.eurostat.ec.europa.eu/portal/page /portal/energy/data/database)

[7] Average Retail Prices of Electricity, U.S. Energy Information Administration. Monthly Energy Review December 2013. (Available at: http://www.eia.gov/totalenergy/data/monthly/pdf/sec9_11.pdf) 